\title{
Herbivores just need a calm place to feed: Ants cannot help them
}

\author{
Antônio C. M. Queiroz ${ }^{1,2=\infty}$, Cibele R. Mendes ${ }^{2} \oplus$, Dalbert B. da Costa ${ }^{2}$
}

\author{
${ }^{1}$ Laboratório de Ecologia de Formigas, DBI, Universidade Federal de Lavras, Lavras, MG, Brazil. ${ }^{2}$ Programa de Pós-Graduação em \\ Ecologia Aplicada. Universidade Federal de Lavras, Lavras, MG, Brazil. \\ 拝三Corresponding author: queirozacm@gmail.com
}

Edited by: Maria F. G. V. Penãflor

Received: May 07, 2020. Accepted: July 26, 2020. Published: August 28, 2020.

\begin{abstract}
Why do herbivores, like Coelomera sp., seek to consume leaf tissue of Cecropia pachystachya colonized by Azteca alfari Emery, 1893 if they are at risk of being attacked by these ants? We collected herbivory data (leaf area lost, occurrence of herbivores and expulsion of enemies by $A$. alfari) in different shifts (times of the day) in 50 C. pachystachya trees ( 25 uncolonized and 25 colonized by $A$. alfari). We registered less leaf area lost and less beetle occurrence in colonized plants. Moreover, the proportion of enemies expelled (killed or removed) is more related to the number of ants that were patrolling and attacking the invaders in the tissue than to the total number of ants present in colonized plants due to $A$. alfari recruitment and behavior. Thus, such herbivores prefer to use tissues of uncolonized plants and tree structures of colonized ones with less active ants given the risk evaluation of encountering a group of aggressive ants. In this way, $C$. pachystachya needs these ants to cover the plant tissues as much as possible to ensure its protection.
\end{abstract}

Keywords: Ant-Plant interactions, Cecropia, Rainforest, Formicidae, Biotic defense, Chewing insects.

Ecological interactions, such as the relationship between ants and myrmecophyte plants, are commonly studied. An example of these interactions is the case of ants that defend Cecropia spp. trees from herbivores, as they nest in the plant and obtain food resources (e.g. Müllerian bodies) (Hölldobler \& Wilson 1990). However, not all of these plants are colonized by ants, and this colonization occurs along the plant development (Del Val \& Dirzo 2003; Oliveira et al. 2015).

When colonized by ants, Cecropia pachystachya trees show a large decrease in herbivory rates (Oliveira et al. 2015), which may be due to increased foraging of ants on leaves (Rocha \& Bergallo 1992). Azteca sp. are dominant, great predators, extremely aggressive and territorial ants (Hölldobler \& Wilson 1990; Longino 1991). These ants help to provide protection that maintain herbivory rates under $20 \%$ (Coley 1983). Besides that, tree protection varies and can be related to: number of ants foraging, shifts (the time of day, related to ant activity), and ant aggressiveness (Barwell 1967; Longino 1991; Rocha \& Bergallo 1992).

In Brazilian Mata Atlântica Rainforest, the relationship between C. pachystachya (Urticaceae) and Azteca alfari Emery, 1893 (Hymenoptera: Formicidae) is quite common (de Oliveira et al. 2015). This interaction system is not exclusively found in forests, and also occurs in open environments where $C$. pachystchya is present (Reis et al. 2013). However, open and closed areas can present different patterns in the presence and ant defense (Carneiro et al. 2018). Cecropia pachystchya can also present a diverse and large number of occasional visitors (Novais et al. 2015), but its main defoliators is Coelomera lanio (Dalman, 1823) (Coleoptera: Chrysomelidae) (Silveira et al. 2002) that also oviposit on it.

In this work, our aim was to understand how herbivores seek to consume leaf tissue of $C$. pachystachya trees in the absence and presence of ants, even at the risk of being attacked by them. We expected that: i) the presence of ants would decrease the leaf area lost and beetle occurrence, ii) The total number of foraging ants was the most important factor in the decrease of the proportion of herbivores expelled from plants.

We collected in clearings or secondary forests areas with large presence of $C$. pachystachya individuals in Reserva Biológica União, located in the municipality of Rio das Ostras, state of Rio de Janeiro, Brazil $\left(22^{\circ} 25^{\prime} 41.38^{\prime \prime} \mathrm{S} ; 42^{\circ} 2^{\prime} 12.24^{\prime \prime} \mathrm{W}\right)$, at $55 \mathrm{~m}$ altitude. This area is under the Mata Atlântica domain and presents rainy summers and dry winters, the average annual temperature is $\sim 23$ 으 and an annual rainfall of $1657.7 \pm 70 \mathrm{~mm}$ (MMA/ICMBIO 2008). We selected $50 \mathrm{C}$. pachystachya individuals (Fig. $1 \mathrm{~A}$ ) that were at least $10 \mathrm{~m}$ apart from each other. Among them, 25 plants presented established $A$. alfari colonies (plants with $\bar{x} 1.95 \mathrm{~m}$ high) (Fig. 1B) and 25 had no A. alfari colonies (plants with $\bar{x} 1.47 \mathrm{~m}$ high). We opened trunk internodes (when necessary) to check if the colony was established, but we did not use trees with opened internodes in the termite experiment. The tallest tree in this work was $2.5 \mathrm{~m}$ high, in order to make the observations possible.

In each of the 50 trees, we randomly removed three leaves, varying their position on the plant as much as possible, and measured the leaf area lost by herbivory (caused by leaf chewers) with digital photographs and the software ImageJ (Rasband 2006). We also searched the plants for checking the presence of Coelomera sp. (Fig. 1C). In the 25 plants with ant presence, we randomly put termites, Nasutitermes sp., during the time of observation in each plant (three per shift, six per plant in total), to freely walk on the leaves in order to simulate the presence of an herbivore (Cogni \& Freitas 2002), in three rounds per shift (time of day). These observations were made from $08 \mathrm{~h} 00$ to $11 \mathrm{~h} 00$ and from $16 \mathrm{~h} 30$ to $18 \mathrm{~h} 30$ ( $\overline{\mathrm{x}} \sim 5 \mathrm{~min}$. per plant). We counted the total number of ants foraging on the plant during both shifts to estimate the total number of ants in the colony, and used the number of ants foraging in each shift. We also counted how many individuals attacked the termites after their release, and calculated the proportion of termites that were killed or removed during the observation time.

We used GLMs to evaluate if plants with the presence of ants or higher colonies have lower proportion of leaf area lost by herbivory (average of leaf area lost in three leaves) and if colonized plants have lower beetle occurrence (presence/absence) in models with quasibinomial and binomial distributions, respectively. We used a GLMM to test for differences in ant foraging in the morning and sunset. After that, we listed six GLMMs and then ranked them through the AICc method to get a best model ranking. Among these six models, 
the proportion of termites killed or removed (expelled) was the explanatory variable with binomial distribution, and the shift, the total number of foraging ants and the number of ants that attacked termites were explanatory variables (Tab. 1). Plants were used as random effect variables in the GLMMs. For that, we used the packages "Ime4" (Bates et al. 2019), "AlCcmodavg" (Mazerolle 2019) and the software R ( $R$ Development Core Team 2019).
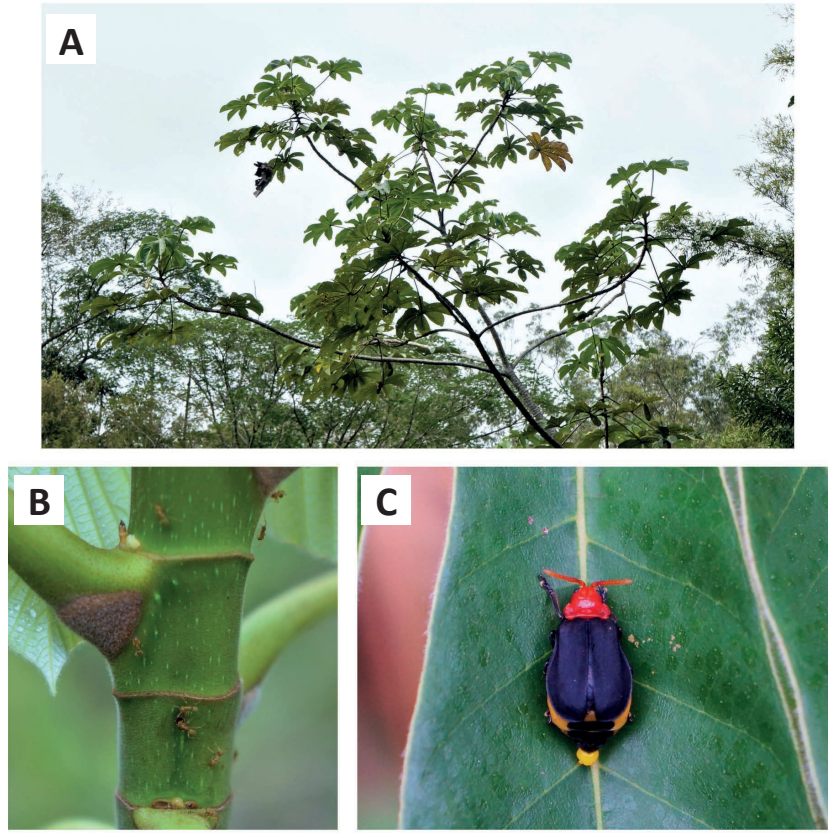

Figure 1. Azteca-Cecropia studied system: A) Cecropia pachystachya tree, B) Azteca alfari ants and the nest entrance in a Cecropia pachystachya plant, C) Coelomera sp. on a Cecropia pachystachya leaf.

In C. pachystachya with ant presence, we found lower proportion of leaf area lost $(F=81.035 ; p<0.001 ; n=50$; Fig. $2 A)$ and a lower occurrence of Coelomera sp. ( $p=0.003$; Fig. 2B) compared with individuals without ants. Regarding the shifts, the number of foraging ants during the morning was higher than during the sunset $(x 2=38.782$; $\mathrm{p}<0.001$; Fig. 2C). Our best model presents a (positive) relationship between the proportion of termites expelled and the number of ants attacking termites (Tab. 1). The total number of ants foraging was not the best predictor, but this predictor variable is also (positively) related to the proportion of termites expelled.

As expected, the presence of ants decreases the leaf area lost and the beetle occurrence in $C$. pachystachya. Leaf area consumption in C. pachystachya trees is related to the presence of defenses (e.g. chemical, trichomes, mutualistic defenders) and the nutritional quality of tissues, and defenses may change depending on plant ontogeny (Schupp 1986; Del Val \& Dirzo 2003). As we observe similar patterns, we suggest that this beetle (or other herbivores) may search for young and nutritive leaves in structures (Mendes et al. 2017) when they are less visited by ants. Ant presence leads to improved plant development (Oliveira et al. 2015) and the presence of Coelomera sp. is less common in colonized plants because ants' presence is an effective defense (Silveira et al. 2002).

\section{A}

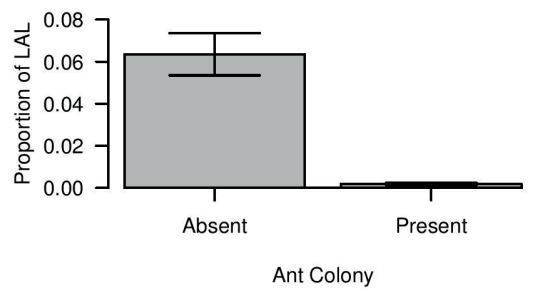

B

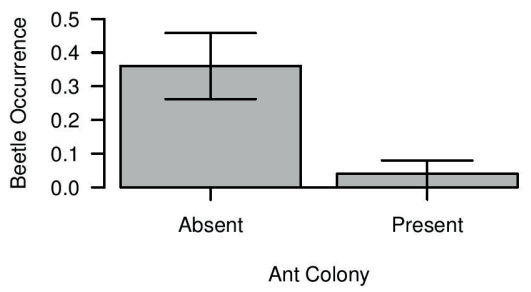

C

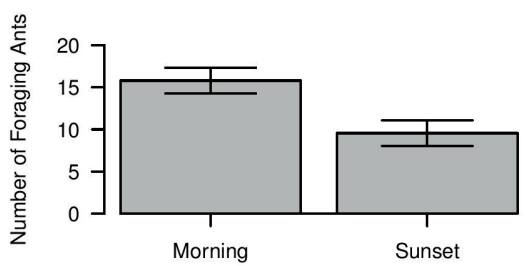

Shift

Figure 2. A) Proportion of leaf area lost (LAL) by herbivory (mean per plant) in Cecropia pachystachya with Azteca alfari absent and present (Mean $\pm \mathrm{SE}, \mathrm{n}=$ 50). B) Occurrence of Coelomera sp. (Absence/Presence) on C. pachystachya with $A$. alfari absent and present (Mean $\pm S E, n=50$ ). C) Number of $A$. alfari foraging in $C$. pachystachya during the morning and sunset (Mean $\pm \mathrm{SE}, \mathrm{n}=25$ ).

However, after tree colonization and establishment of $A$. alfari colony, the decrease in herbivory rates depends not only on the number of ants, but also on their recruitment and behavior. Azteca alfari decreases its activity throughout the day (Barwell 1967) and the number of foraging ants is reported as determinant in the expulsion of herbivores and may be related to the size of plants and their colonies (Rocha \& Bergallo 1992). However, contrary to our predictions, the total number of ants foraging was not our best model to explain herbivore removal or killing. We observed that the number of attacker ants is the most important factor for expelling herbivores. The strongest relationship with the number of attackers probably occurs due to $A$. alfari type of recruitment. These ants recruit, through pheromones, nestmates that are close within the alarm pheromone range, which is called short-range recruitment (Dejean et al. 2009). We have not yet seen quantitatively that this characteristic is more important for effective exclusion of herbivores than the total number of ants foraging per se. Besides that, once the colony personality can be independent of colony size or tree size, workers in younger colonies are capable to

Table 1. Model selection based on the second-order Akaike information criterion (AICC) for proportion of termites killed or removed (expelled). The GLMM models were built with binomial distribution, plant as random variable and the following fixed explanatory variables: number of ants that attacked termites (Attackers), Shift (morning or sunset), and the total number of foraging ants on plants (All Foraging). Number of predictor variables (K), differences in AICc-values ( $\Delta$ ), and Akaike weight $(\omega)$.

\begin{tabular}{|c|c|c|c|c|c|c|c|}
\hline Ranking & Model & K & $\mathrm{AlCc}$ & $\Delta$ & $\Omega$ & Cumulated $\omega$ & Log Likelihood \\
\hline 1 & Attackers & 3 & 58.28 & 0.00 & 0.56 & 0.56 & -25.88 \\
\hline 2 & Attackers + Shift & 4 & 60.42 & 2.14 & 0.19 & 0.75 & -25.77 \\
\hline 3 & All Foraging & 3 & 60.84 & 2.55 & 0.16 & 0.90 & -27.16 \\
\hline 4 & All Foraging + Shift & 4 & 62.62 & 4.33 & 0.06 & 0.97 & -26.86 \\
\hline 5 & Shift & 3 & 65.12 & 6.83 & 0.02 & 0.99 & -29.30 \\
\hline 6 & Intercept & 2 & 65.58 & 7.30 & 0.01 & 1.00 & -30.66 \\
\hline
\end{tabular}


protect $C$. pachystachya trees being more aggressive than workers in mature colonies (Marting et al. 2018). So, we can observe plants with slightly smaller colonies but with very active and aggressive ants that expel enemies and protect trees effectively.

In this way, herbivores take advantage of the enemy-free space (Jeffries \& Lawton 1984) when they choose to feed on uncolonized plants and colonized plants at times and/or structures where ants are less active (safer to consume leaf tissue). Additionally, C. pachystachya needs ants to cover the plant tissues as much as possible for total protection. In other words, in our work, the use of the plant tissues by herbivores can be related not only to total number of ants foraging, the time of day or colony size but, mainly, to the number of attackers due to the type of recruitment of the species. So, the Azteca-Cecropia system can alter the occurrence and behavior of herbivores, as Coelomera sp., which prefer plants and tissues where they will not be expelled by ants. Thus, we reinforce the need to evaluate the nuances and idiosyncrasies of the interactions and suggest new studies focusing on herbivores behavior on myrmecophytic plants.

\section{Acknowledgements}

This study was carried out during the Field Ecology course from Ecologia Aplicada Graduate Program (Universidade Federal de Lavras). We thank L. Prado, M. Biondi, and E. van den Berg for helping to confirm the identification of species, C. Lasmar, S. Novais, E. Mousinho, and other anonymous referees for their comments and criticisms on the manuscript. Reserva Biológica União (MMA/ICMBIO) and Universidade Federal de Lavras (UFLA) provided us with logistic support. During the study ACMQ received a scholarship from the Coordenação de Aperfeiçoamento de Pessoal de Nível Superior (Capes). ACMQ has a CEMIG postdoctoral fellowship.

\section{Authors' Contributions}

$A C M Q$ analyzed the data and wrote the original draft. ACMQ, CRM, DBC conceived and designed the research, wrote and edited the manuscript.

\section{References}

Barwell, F. H. (1967) Daily patterns in the activity of the arboreal ant Azteca alfari. Ecology, 48(6): 991-993. doi: 10.2307/1934549

Bates, D.; Maechler, M.; Bolker, B.; Walker, S.; Christensen, R. H. B.; Singmann, H.; Dai, B.; Scheipl, F.; Grothendieck, G.; Green, P.; Fox, J. (2019) Package 'Ime4'. Linear mixed-effects models using S4 classes. R package version, 1-1-21.

Carneiro, M. A. F.; Gaglioti, A. L.; Carvalho, K. S.; Nascimento, I. C.; Zina, J. (2018) The Habitat Affects the Ecological Interactions between Azteca Forel (Hymenoptera: Formicidae) and Cecropia Loefl. (Urticaceae Juss.). Sociobiology, 65(2), 177-184. doi: 10.13102/sociobiology.v65i2.2044

Cogni, R.; Freitas, A. V. (2002) The ant assemblage visiting extrafloral nectaries of Hibiscus pernambucensis (Malvaceae) in a mangrove forest in southeast Brazil (Hymenoptera: Formicidae). Sociobiology, 40(2): 373-383.

Coley, P. D. (1983) Intraspecific variation in herbivory on two tropical tree species. Ecology, 64(3): 426-433. doi: 10.2307/1939960

de Oliveira, G. V.; Corrêa, M. M.; Góes, I. M.; Machado, A. F.; de SáNeto, R. J.: Delabie, J. H. (2015) Interactions between Cecropia (Urticaceae) and ants (Hymenoptera: Formicidae) along a longitudinal east-west transect in the Brazilian Northeast. Annales de la Société entomologique de France, 51(2): 153-160. doi: 10.1080/00379271.2015.1061231

Del Val, E.; Dirzo, R. (2003) Does ontogeny cause changes in the defensive strategies of the myrmecophyte Cecropia peltata? Plant Ecology, 169(1): 35-41. doi: 10.1023/A:1026227811685

Dejean, A.; Grangier, J.; Leroy, C.; Orivel, J. (2009) Predation and aggressiveness in host plant protection: a generalization using ants from the genus Azteca. Naturwissenschaften, 96(1): 57-63. doi: 10.1007/s00114-008-0448-y

Hölldobler, B.; Wilson, E.O. (1990) The Ants. Cambridge: Harvard University Press.

Jeffries, M. J.; Lawton, J. H. (1984) Enemy free space and the structure of ecological communities. Biological journal of the Linnean Society, 23(4): 269-286. doi: 10.1111/j.1095-8312.1984.tb00145.x

Longino, J. T. (1991) Taxonomy of the Cecropia-inhabiting Azteca ants. Journal of Natural History, 25(6): 1571-1602. doi: 10.1080/00222939100770981

Mazerolle, M. J. (2019) Package 'AlCcmodavg'. R package version, 2.2-2.

Mendes, G. M.; Cornelissen, T. G. (2017) Effects of plant quality and ant defence on herbivory rates in a neotropical ant-plant. Ecological Entomology, 42(5): 668-674. doi: 10.1111/een.12432

MMA/ICMBIO (2008) Plano de Manejo Reserva Biológica União. Reserva Biológica União: Rio de Janeiro. https://www.icmbio.gov.br/portal/ images/stories/imgs-unidades-coservacao/ENCARTE\%204_rebio. pdf. Access on 5.viii.2020

Marting, P. R.; Kallman, N. M.; Wcislo, W. T.; Pratt, S. C. (2018) Ant-plant sociometry in the Azteca-Cecropia mutualism. Scientific reports, 8(1): 1-15. doi: 10.1038/s41598-018-36399-9

Novais, S. M. A.; Alvarenga, A. S.; Falcão, L. A. D.; Neves, F. S. (2015) Vertical stratification and effect of petiole and dry leaf size on arthropod feeding guilds in Cecropia pachystachya (Urticaceae). Brazilian Journal of Biology, 75(3): 517-523. doi: 10.1590/15196984.15213

Oliveira, K. N.; Coley, P. D.; Kursar, T. A.; Kaminski, L. A.; Moreira, M. Z.; Campos, R. I. (2015) The effect of symbiotic ant colonies on plant growth: a test using an Azteca-Cecropia system. PloS one, 10(3), e0120351. doi: 10.1371/journal.pone.0120351

R Development Core Team. (2019) R: a language and environment for statistical computing. Version 3.6.1. Vienna: R Foundation for Statistical Computing. http://www.r-project.org

Rasband, W. S. (2006) ImageJ. Bethesda. Maryland: U.S. National Institutes of Health. http://rsb.info.nih.gov/ij

Reis, P. C.; Da Rocha, W. D.; Falcão, L. A.; Guerra, T. J.; Neves, F. S. (2013) Ant fauna on Cecropia pachystachya Trécul (Urticaceae) trees in an Atlantic Forest area, southeastern Brazil. Sociobiology, 60(3): 222228. doi: 10.13102/sociobiology.v60i3.222-228

Rocha, C. F. D.; Bergallo, H. G. (1992) Bigger ant colonies reduce herbivory and herbivore residence time on leaves of an ant-plant: Azteca muelleri vs. Coelomera ruficornis on Cecropia pachystachya. Oecologia, 91(2): 249-252. doi: 10.1007/BF00317792

Schupp, E. W. (1986) Azteca protection of Cecropia: ant occupation benefits juvenile trees. Oecologia, 70(3): 379-385. doi: 10.1007/ BF00379500

Silveira, R. D.; dos Anjos, N.; Zanuncio, J. C. (2002) Natural enemies of Coelomera lanio (Coleoptera: Chrysomelidae) in the region of Viçosa, Minas Gerais, Brazil. Revista de Biología Tropical, 50(1): 117-120. 